Marquette University

e-Publications@Marquette

10-2007

\title{
Generation of molecular complexity from cyclooctatetraene: synthesis of a protected 2-(3'-carboxy-2'- benzoylcyclopentyl)glycine
}

Subhabrata Chaudhury

Marquette University

Sergey Lindeman

Marquette University, sergey.lindeman@marquette.edu

William Donaldson

Marquette University, william.donaldson@marquette.edu

Follow this and additional works at: https://epublications.marquette.edu/chem_fac

Part of the Chemistry Commons

\section{Recommended Citation}

Chaudhury, Subhabrata; Lindeman, Sergey; and Donaldson, William, "Generation of molecular complexity from cyclooctatetraene: synthesis of a protected 2-(3'-carboxy-2'-benzoylcyclopentyl)glycine" (2007).

Chemistry Faculty Research and Publications. 49.

https://epublications.marquette.edu/chem_fac/49 
Marquette University

e-Publications@Marquette

\section{Chemistry Faculty Research and Publications/College of Arts and Sciences}

This paper is NOT THE PUBLISHED VERSION; but the author's final, peer-reviewed manuscript. The published version may be accessed by following the link in the citation below.

Tetrahedron Letters, Vol. 48, No. 44 (October 29, 2007): 7849-7852. DOI. This article is (C) Elsevier and permission has been granted for this version to appear in e-Publications@Marquette. Elsevier does not grant permission for this article to be further copied/distributed or hosted elsewhere without the express permission from Elsevier.

\section{Generation Of Molecular Complexity From Cyclooctatetraene: Synthesis Of A Protected 2-(3'-Carboxy-2'-Benzoylcyclopentyl)Glycine}

Subhabrata Chaudhury

Department of Chemistry, Marquette University, Milwaukee, WI

Sergey Lindeman

Department of Chemistry, Marquette University, Milwaukee, WI

William A. Donaldson

Department of Chemistry, Marquette University, Milwaukee, WI

\section{Abstract}

Synthesis of a protected 2-(3'-carboxycyclopentyl)glycine rac-11, possessing four contiguous chiral carbons, was accomplished in six steps ( $20 \%$ yield) from the hydrocarbon cyclooctatetraene. 


\section{Graphical abstract}

Synthesis of a protected 2-(3'-carboxycyclopentyl)glycine rac-11, possessing four contiguous chiral carbons, was accomplished in six steps ( $20 \%$ yield) from the hydrocarbon cyclooctatetraene.
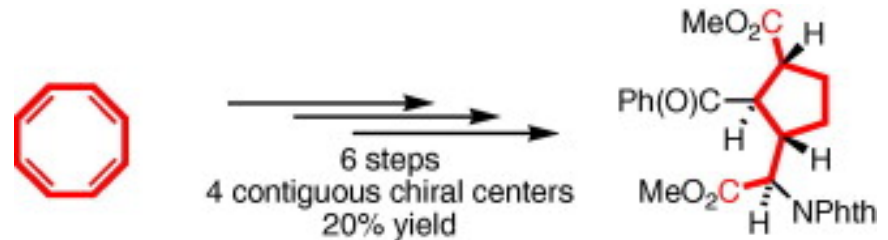

The use of the simple hydrocarbon cyclooctatetraene (1) as a starting material for synthesis has experienced a rebirth in the last five years, as exemplified by its use in the synthesis of aminocyclitols, $\underline{\underline{1 a}}$ bishomoconduritols, $\underline{\underline{1 b}}$ bis-homoinositol, $\underline{\underline{1 c}}$ pentacycloanammoxic acid methyl ester, $\underline{\underline{1 d}}$ the polyene segment of roxaticin, $\underline{\underline{1 e}}$ and cyclooctitols. ${ }^{\frac{1 f}{f}}$ Tricarbonyl(cyclooctatetraene)iron $\mathbf{2}$, readily prepared from $\mathbf{1}, \underline{\underline{2}}$ undergoes reaction with electrophiles to give a wide variety of cationic iron complexes 3 (Scheme 1 ). Protonation $3(\mathrm{a}), \underline{3(\mathrm{~b})}$ of $\mathbf{2}$ or its $(\mathrm{CO})_{2} \mathrm{PPh}_{3}$ ligated analog affords (bicyclo[5.1.0] octadienyl) $\mathrm{Fe}(\mathrm{CO})_{2} \mathrm{~L}^{+}$cations 3. We have previously demonstrated the applicability of cation $\mathbf{3 b}$ for the synthesis of the naturally occurring CCGIII (4). ${ }^{4}$ In contrast, Friedel-Crafts acylation of $\mathbf{2}$, followed by anion metathesis, gave

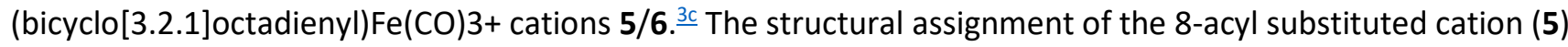
was eventually confirmed by X-ray crystal structure. ${ }^{-}$In comparison to the extensive examination of (cyclohexadienyl)- and (cycloheptadienyl)-iron(1+) cations, $\underline{6}, \underline{7}$ the reactivity of bicyclic cations $\mathbf{5 / 6}$ with nucleophiles has been considerably less studied.3(c), $\underline{8}$ As part of our growing interest in the generation of molecular complexity from hydrocarbons, $-\underline{4}$ we herein report on the reactivity of cation $\mathbf{6}$ and the synthesis of a protected 2-(3-carboxycyclopentyl)glycine from 1.

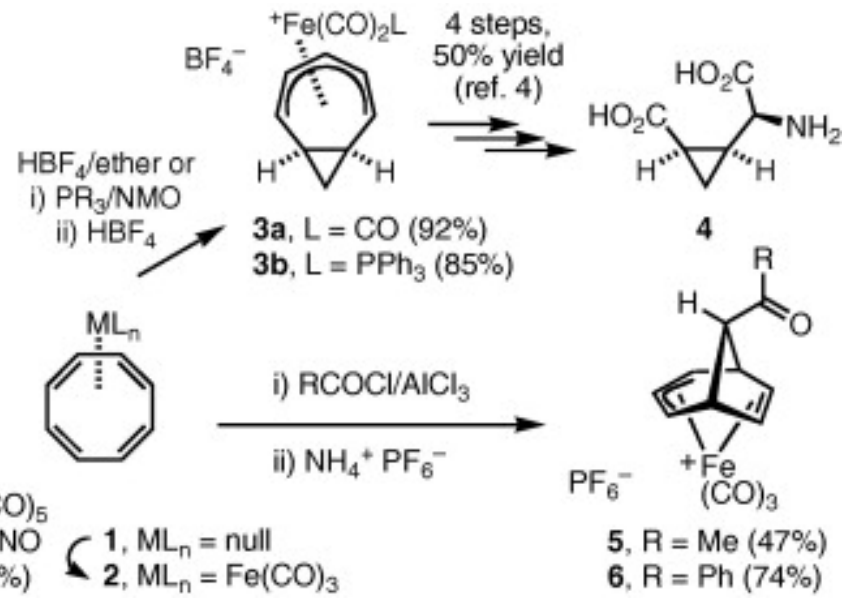

Scheme 1.

The reaction of $\mathbf{6}$ with $\mathrm{BH} 4$ - gave a mixture of diene complex 7a and the free ligand $8 \mathrm{a}$; decomposition of this mixture by irradiation with a medium pressure $\mathrm{Hg}$ lamp in acetic acid solution gave only 8a (Table 1). In a similar fashion, reaction of $\mathbf{6}$ with $\mathrm{MeLi} / \mathrm{CuBr}$, followed by decomplexation, gave $\mathbf{8 b}$ albeit in attenuated yield. In comparison, reaction of 6 with triphenylphosphine, dimethyl malonate, dimethyl allylmalonate, or phthalimide gave diene complexes $\mathbf{7 c - f}$ in good isolated yield. Decomplexation of $\mathbf{7 d}$ or $\mathbf{7 f}$ gave the 4-substituted-8-

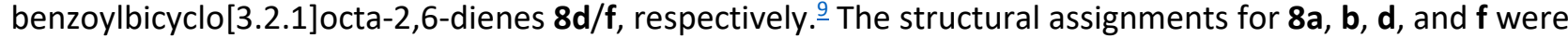
based on their ${ }^{1} \mathrm{H}$ NMR spectral data. In particular, the signals for $\mathrm{H1}, \mathrm{H} 2, \mathrm{H} 3, \mathrm{H} 6$, and $\mathrm{H} 7$ appear at $\delta$ 3.1-3.4 
(dd), 6.2-6.5 (ddd), 5.2-5.5 (dd), 5.6-6.0 (dd), and 6.1-6.35 (dd) ppm, respectively. Furthermore, the structures of $8 \mathbf{a}$ and $7 \mathrm{c}$ were corroborated by X-ray diffraction analysis (Fig. 1)..$\underline{10}$
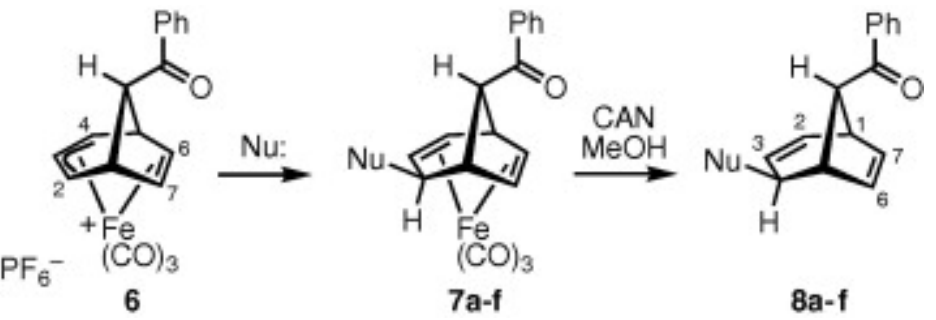

8a-f

Table 1. Nucleophilic addition to (8-benzoylbicyclo[3.2.1octa-3,6-dien-2-yl) Fe(CO)3+

\begin{tabular}{|l|l|l|l|}
\hline Nucleophile & $\mathrm{Nu}$ & Products (isolated yield, \%) & \\
\hline $\mathrm{NaBH}_{4}$ & $\mathrm{H}$ & 7a (-) & 8a (41) \\
\hline $\mathrm{MeLi} / \mathrm{CuBr}$ & $\mathrm{Me}$ & 7b (-) & $8 \mathrm{~b}(23)$ \\
\hline $\mathrm{PPh}_{3}$ & PPh3+PF6- & 7c (85) & - \\
\hline $\mathrm{NaCH}\left(\mathrm{CO}_{2} \mathrm{Me}\right)_{2}$ & $\mathrm{CH}\left(\mathrm{CO}_{2} \mathrm{Me}\right)_{2}$ & 7d (98) & 8d (99) \\
\hline $\mathrm{NaC}\left(\right.$ allyl) $\left(\mathrm{CO}_{2} \mathrm{Me}\right)_{2}$ & $\mathrm{C}\left(\right.$ allyl) $\left(\mathrm{CO}_{2} \mathrm{Me}\right)_{2}$ & 7e (95) & - \\
\hline $\mathrm{K}^{+-} \mathrm{NPhth}$ & NPhth & 7f (82-89) & 8f (87-99) \\
\hline
\end{tabular}

a The (diene) $\mathrm{Fe}(\mathrm{CO})_{3}$ complex 7a was decomposed by irradiation with a medium pressure $\mathrm{Hg}$ lamp in acetic acid solution.
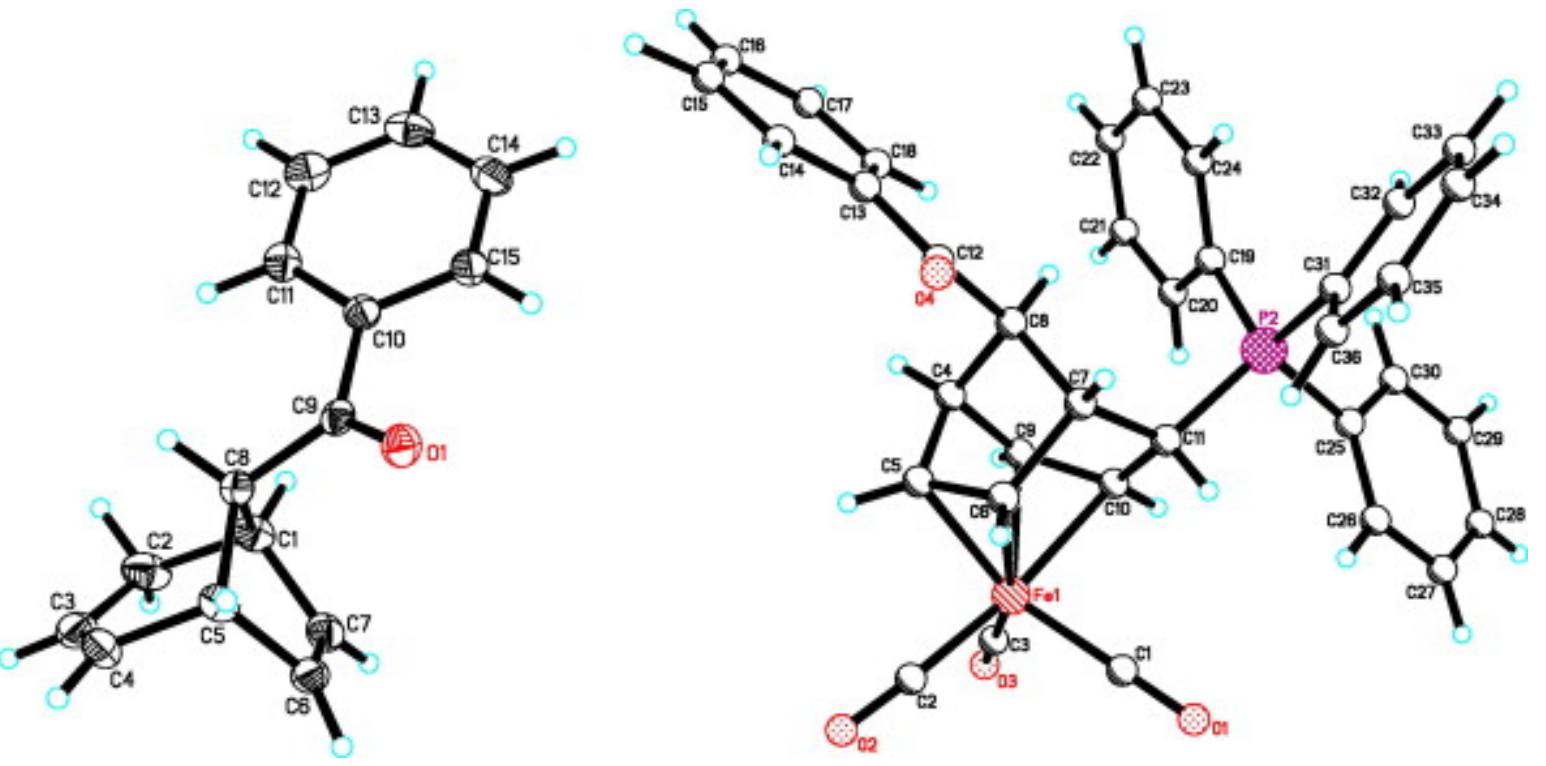

Figure 1. Molecular representations of 8a (left) and 7c (right, PF6- omitted).

Nucleophilic addition to C2/C4 of 6 is opposite to the predicted regioselectivity from the 'Green-Mingos-Davies rules' $\underline{11}$ for nucleophilic addition to cationic polyenyl-metal complexes, (i.e.,'even' polyenyl ligands in preference to 'odd' polyenyl ligands). The observed regioselectivity can be rationalized on the basis of steric hindrance for attack at C6/C7 due to the pendant C8 benzoyl group. Incorporation of non-proteinogenic amino acids or peptide isosteres into proteins or small peptides is of interest due to an increase in proteolytic resistance of the modified protein and/or conformational rigidity imparted due to the structure of the unusual amino acid. $\frac{12}{}$ Recently, Pellegrino reported the synthesis of 2-(3'-carboxycyclopentyl)-glycines $9 \mathbf{a} / \mathbf{b}$ as conformationally restricted analogs, the naturally occurring, but rare, amino acids 2 -aminoadipic acid and 2-aminopimelic acid. ${ }^{13}$ It was envisioned that bicyclo[3.2.1] octa-2,6-diene $8 \mathrm{f}$ could be elaborated into a derivative of 9a. To this end, selective reduction of $\mathrm{C} 6-\mathrm{C} 7$ double bond of $\mathbf{8 f}$ with $\mathrm{H}_{2}$ (balloon pressure, $\mathrm{RhCl}\left(\mathrm{PPh}_{3}\right)_{3}, 45 \mathrm{~min}$ ) cleanly gave 
mono-olefin 10 (Scheme 2)..$\underline{14}$ Use of greater pressure (50 psi) or longer reaction times leads to partial reduction of the C2-C3 olefin. The greater reactivity of the C6-C7 olefin in a bicyclo[3.2.1]octa-2,6-diene system, toward oxidation, reduction, or addition, compared to the $\mathrm{C} 2-\mathrm{C} 3$ olefin is well documented. $\frac{15}{}$ This selectivity is generally attributed to the greater strain inherent in the $\mathrm{C} 6-\mathrm{C} 7$ olefin compared to the $\mathrm{C} 2-\mathrm{C} 3$ olefin. ${ }^{15 \mathrm{~d}}$ Sharpless oxidation $\left(\mathrm{RuCl}_{3} / \mathrm{IO} 4-\right)^{\frac{16}{6}}$ of 10, followed by Fisher esterification gave diester $11 .{ }^{17}$ The structural assignment for 11 was tentatively based on its NMR spectral data. In particular, the doublet for $\mathrm{H}_{a}$ appears at $\delta 4.95$, while the two methyl esters singlets appear at $\delta 3.62$ and $3.44 \mathrm{ppm}$. This structural assignment was also corroborated by X-ray diffraction analysis of $\mathbf{1 1}$ (ig. 2 )..$\underline{10}$

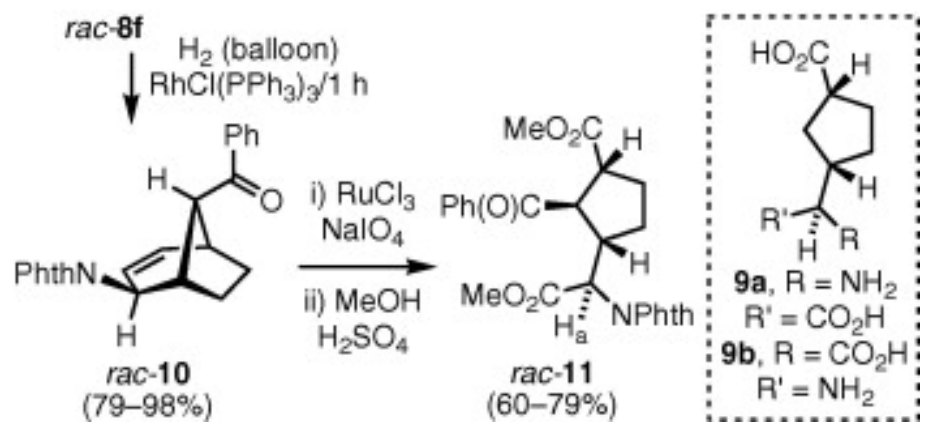

Scheme 2 .

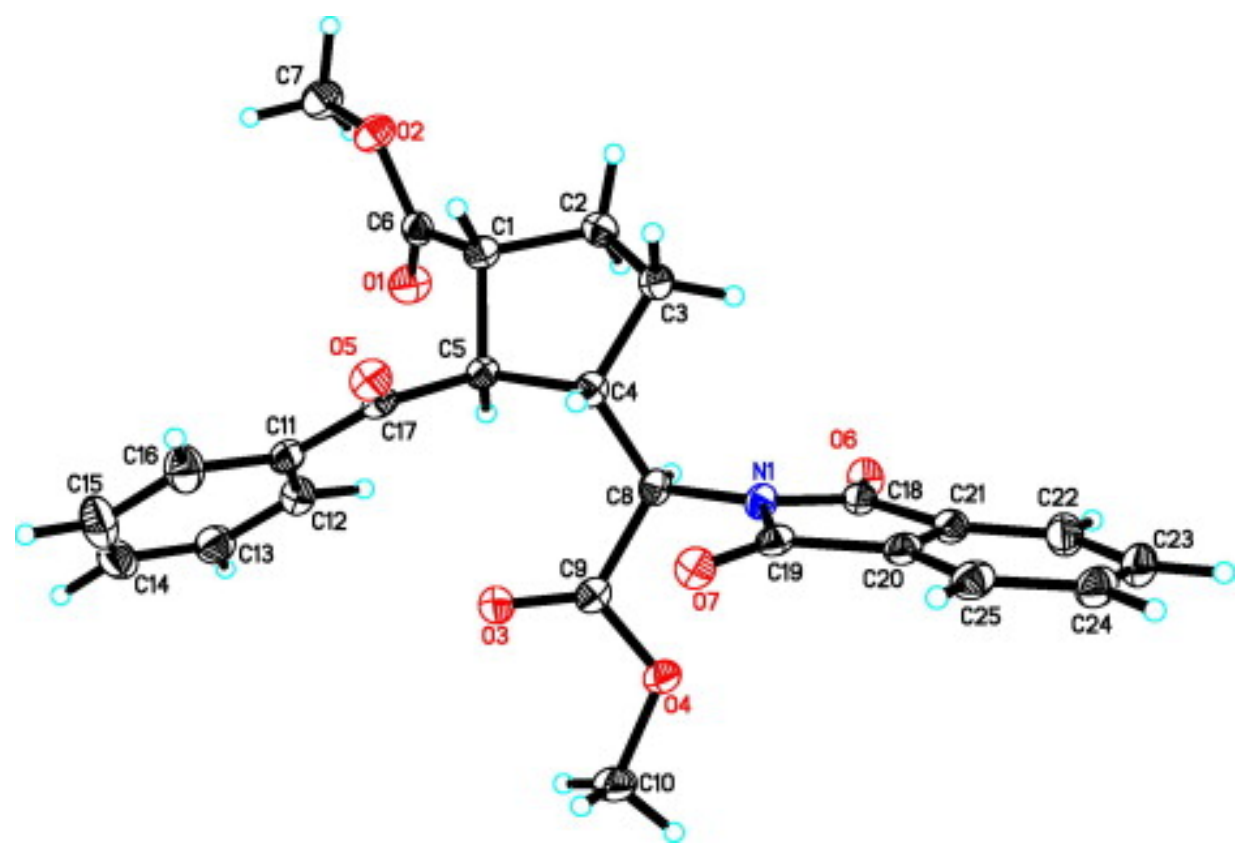

Figure 2. Molecular representation of $\mathbf{1 1 .}$

In summary, (8-benzoylbicyclo[3.2.1]octa-3,6-dien-2-yl)Fe(CO)3+ cation 6 reacts with a variety of nucleophiles by attack at the $\eta^{3}$-allyl fragment to generate diene complexes 7 . This reactivity was utilized in a short synthesis of the protected amino acid analog 11, possessing four contiguous chiral centers, from the simple hydrocarbon cyclooctatetraene.

\section{Acknowledgments}

This work was supported by the National Science Foundation (CHE-0415771) and NSF instrumentation grants (CHE-0521323). High-resolution mass spectra were obtained at the University of Nebraska-Center for Mass Spectrometry. 


\section{References and notes}

1 (a) L. Kelebekli, M. Celik, E. Sahin, Y. Kara, M. Balci, Tetrahedron Lett., 47 (2006), pp. 7031-7035 (b) L. Kelebekli, Y. Kara, M. Balci, Carbohydr. Res., 340 (2005), pp. 1940-1948 (c) Y. Kara, M. Balci, Tetrahedron, 59 (2003), pp. 2063-2066 (d) V. Mascitti, E.J. Corey, J. Am. Chem. Soc., 126 (2004), pp. 15664-15665 (e) D.A. Evans, B.T. Connell, J. Am. Chem. Soc., 125 (2003), pp. 10899-10905 (f) G. Metha, K. Pallavi, Chem. Commun. (2002), pp. 2828-2829

2 Y. Shvo, E. Hazum, J. Chem. Soc., Chem. Commun. (1975), pp. 829-830

3 (a) A. Davison, W. McFarlane, L. Pratt, G. Wilkinson, J. Chem. Soc. (1962), pp. 4821-4829 (b) M. Brookhart, E.R. Davis, D.L. Harris, J. Am. Chem. Soc., 94 (1972), pp. 7853-7858 (c) A.D. Charles, P. Diversi, B.F.G. Johnson, J. Lewis, J. Chem. Soc., Dalton Trans. (1981), pp. 1906-1917 (d) N.G. Connelly, A.R. Lucy, M.W. Whiteley, J. Chem. Soc., Dalton Trans. (1983), pp. 111-115 (e) K. Broadley, N.G. Connelly, R.M. Mills, M.W. Whiteley, P. Woodward, J. Chem. Soc., Dalton Trans. (1984), pp. 683-688 (f) K. Broadley, N.G. Connelly, P.G. Graham, J.A.K. Howard, W. Risse, M.W. Whiteley, J. Chem. Soc., Dalton Trans. (1985), pp. 777-781

4 N.J. Wallock, W.A. Donaldson, J. Org. Chem., 69 (2004), pp. 2997-3007

5 A.V. Rivera, G.M. Sheldrick, Acta Crystallogr. Sect. B, 34 (1978), pp. 1716-1718

6 (a) A.J. Pearson, E.W. Abel, F.G.A. Stone, G. Wilkenson (Eds.), Comprehensive Organometallic Chemistry II, Vol. 12, Pergamon Press, Oxford, UK (1995), pp. 637-683 (b) A.J. Pearson, L.S. Liebeskind (Ed.), Advances in Metal-Organic Chemistry, Vol. 1, JAI Press, Greenwich, CT (1989), pp. 1-49 (c) H.-J. Knoelker, Chem. Soc. Rev., 28 (1999), pp. 151-157

7 (a) A.J. Pearson, S.L. Kole, T. Ray, J. Am. Chem. Soc., 106 (1984), pp. 6060-6074 (b) A.J. Pearson, M.P. Burello, Organometallics, 11 (1992), p. 448 (c) A.J. Pearson, K. Srinivasan, J. Org. Chem., 57 (1992), p. 3965 (d) A.J. Pearson, K. Srinivasan, Synlett (1992), p. 983 (e) A. Hirschfelder, P. Eilbracht, Synthesis (1996), p. 488

8 S. Huffer, M. Wieser, K. Polborn, W. Beck, J. Organomet. Chem., 481 (1994), pp. 45-55

9 To a solution of $7 f(50 \mathrm{mg}, 0.10 \mathrm{mmol}$ ) in methanol was added CAN (109 mg, $0.200 \mathrm{mmol})$ in one portion. The reaction mixture was stirred for $1 \mathrm{~h}$ and then water $(10 \mathrm{~mL})$ was added and the mixture extracted with ethyl acetate. The combined organic extracts were dried $\left(\mathrm{MgSO}_{4}\right)$ and concentrated under reduced pressure. The residue was purified by column chromatography $\left(\mathrm{SiO}_{2}\right.$, hexane-ethyl acetate $\left.=5: 1\right)$ to afford $8 f$ as a colorless solid ( $35 \mathrm{mg}, 99 \%): \mathrm{mp} 130-132{ }^{\circ} \mathrm{C} ;{ }^{1} \mathrm{H} \mathrm{NMR}\left(\mathrm{CDCl}_{3}\right) \delta 7.88(\mathrm{~m}, 4 \mathrm{H}), 7.76(\mathrm{~m}, 2 \mathrm{H})$, $7.45(\mathrm{~m}, 1 \mathrm{H}), 7.36(\mathrm{~m}, 2 \mathrm{H}), 6.51$ (ddd, $J=2.6,6.8,9.6 \mathrm{~Hz}, 1 \mathrm{H}), 6.35(\mathrm{dd}, J=3.0,5.6 \mathrm{~Hz}, 1 \mathrm{H}), 5.99$ (dd, $J=3.0,5.6 \mathrm{~Hz}, 1 \mathrm{H}), 5.43$ (ddd, $J=2.0,3.0,9.5 \mathrm{~Hz}, 1 \mathrm{H}), 4.78(\mathrm{~s}, 1 \mathrm{H}), 4.72(\mathrm{dt}, J=1.2,2.7 \mathrm{~Hz}, 1 \mathrm{H}), 3.38$ $(\mathrm{dd}, J=2.9,6.7 \mathrm{~Hz}, 1 \mathrm{H}), 3.04(\mathrm{~m}, 1 \mathrm{H}) ;{ }^{13} \mathrm{C} \mathrm{NMR}\left(\mathrm{CDCl}_{3}\right) \delta 200.8,168.6,140.9,136.5,136.2,134.5,132.9$, 131.9, 129.0, 128.7, 128.5, 123.8, 123.5, 56.2, 49.7, 47.7, 42.7. FAB-HRMS $m / z 356.1290$ (calcd for $\left.\mathrm{C}_{23} \mathrm{H}_{18} \mathrm{NO}_{3}\left(\mathrm{M}+\mathrm{H}^{+}\right) \mathrm{m} / \mathrm{z} 356.1287\right)$.

10 The crystallographic data has been deposited with the CCDC for compounds 8 a (CCDC 644516), 7c (CCDC 644515) and 11 (CCDC 644517), respectively. These data can be obtained free of charge at www.ccdc.cam.ac.uk/conts/retreiving.html or from the Cambridge Crystallographic Data Centre, 12 Union Road, Cambridge CB12 1EZ, UK; fax: +44 (1223)336033; e-mail: deposit@ccdc.ccdc.cam.ac.uk.

11 S.G. Davies, M.L.H. Green, D.M.P. Mingos, Tetrahedron, 34 (1978), pp. 3047-3077

12 (a) A. Reichelt, S.F. Martin, Acc. Chem. Res., 39 (2006), pp. 433-442 (b) J.M. Humphrey, A.R. Chamberlin, Chem. Rev., 97 (1997), pp. 2243-2266

13 (a) C. Cabrele, F. Clerici, R. Gandolfi, M.L. Gelmi, F. Molinari, S. Pellegrino, Tetrahedron, 62 (2006), pp. $3502-$ 3508 (b) F. Caputo, F. Clerici, M.L. Gelmi, S. Pellegrino, T. Pilati, Tetrahedron: Asymmetry, 17 (2006), pp. 61-67 (c) F. Clerici, M.L. Gelmi, S. Pellegrino, T. Pilati, J. Org. Chem., 68 (2003), pp. 5286-5291

14 To a solution of $8 f(90 \mathrm{mg}, 0.25 \mathrm{mmol})$ in ethanol $(10 \mathrm{~mL})$ was added $\mathrm{RhCl}\left(\mathrm{PPh}_{3}\right)_{3}(135 \mathrm{mg}, 0.146 \mathrm{mmol})$. The mixture was stirred under a balloon of $\mathrm{H}_{2}$ for $1 \mathrm{~h}$. The mixture was concentrated and the residue was purified by column chromatography $\left(\mathrm{SiO}_{2}\right.$, hexane-ethyl acetate $\left.=5: 1\right)$ to afford $\mathbf{1 0}$ as a colorless solid (88 mg, 98\%): ${ }^{1} \mathrm{H} \mathrm{NMR}\left(\mathrm{CDCl}_{3}\right) \delta 7.95(\mathrm{~m}, 2 \mathrm{H}), 7.84(\mathrm{~m}, 2 \mathrm{H}), 7.71(\mathrm{~m}, 2 \mathrm{H}), 7.51(\mathrm{~m}, 1 \mathrm{H}), 7.41(\mathrm{~m}, 2 \mathrm{H}), 6.39$ 
(ddd, $J=2.1,6.9,9.4 \mathrm{~Hz}, 1 \mathrm{H}$ ), 5.61 (ddd, $J=1.6,3.9,9.3 \mathrm{~Hz}, 1 \mathrm{H}$ ), 4.64 (ddd, $J=2.0,2.7,4.5 \mathrm{~Hz}, 1 \mathrm{H}$ ), 4.41 (s, 1H), $2.94(\mathrm{br} \mathrm{t}, J=5.8 \mathrm{~Hz}, 1 \mathrm{H}), 2.77(\mathrm{~d}, J=8.1 \mathrm{~Hz}, 1 \mathrm{H}), 2.30(\mathrm{~m}, 1 \mathrm{H}), 1.67(\mathrm{~m}, 2 \mathrm{H}), 1.51(\mathrm{~m}, 1 \mathrm{H}) ;{ }^{13} \mathrm{C}$ $\operatorname{NMR}\left(\mathrm{CDCl}_{3}\right) \delta 201.8,168.9,137.9,136.2,134.3,133.0,132.0,128.8,128.7,123.4,122.0,56.5,50.5$, 42.2, 40.3, 31.3, 27.9. FAB-HRMS $m / z 358.1455$ (calcd for $\mathrm{C}_{23} \mathrm{H}_{20} \mathrm{NO}_{3}\left(\mathrm{M}+\mathrm{H}^{+}\right) \mathrm{m} / \mathrm{z} 358.1443$ ).

15 (a) J.S. Clark, M.-R. Clarke, J. Clough, A.J. Blake, C. Wilson, Tetrahedron Lett., 45 (2004), pp. $9447-9450$ (b) W. Ng, H. Lin, Q. Tan, S.J. Danishefsky, Tetrahedron Lett., 43 (2002), pp. 545-548 (c)

R. Kiattansakal, J.K. Snyder, Tetrahedron Lett., 40 (1999), pp. 1079-1082 (d)

F.W. Ng, P. Chiu, S.J. Danishefsky, Tetrahedron Lett., 39 (1998), pp. 767-770 (e)

E. Piers, M. Jean, P.S. Marrs, Tetrahedron Lett., 28 (1987), pp. 5075-5078

16 P.H.J. Carlsen, T. Katsuki, V.S. Martin, K.B. Sharpless, J. Org. Chem., 46 (1981), pp. 3936-3938

$17 \mathrm{To}$ a solution of 10 (100 mg, $0.280 \mathrm{mmol})$ and $\mathrm{NalO}_{4}(478 \mathrm{mg}, 2.23 \mathrm{mmol})$ in $\mathrm{CCl}_{4}(2.5 \mathrm{~mL}), \mathrm{CH}_{3} \mathrm{CN}(2.5 \mathrm{~mL})$, and water $(4 \mathrm{~mL})$ was added $\mathrm{RuCl}_{3} \cdot 3 \mathrm{H}_{2} \mathrm{O}(85 \mathrm{mg}, 0.33 \mathrm{mmol})$. After stirring at room temperature for $3 \mathrm{~h}$, ethyl acetate $(15 \mathrm{~mL})$ and brine $(10 \mathrm{~mL})$, and water $(25 \mathrm{~mL})$ were added to the dark solution. The pink organic phase was separated, and the aqueous phase extracted several times with ethyl acetate. The organic extracts were combined, dried $\left(\mathrm{MgSO}_{4}\right)$, and concentrated. The residue was dissolved in methanol $(10 \mathrm{~mL})$, and concentrated $\mathrm{H}_{2} \mathrm{SO}_{4}$ ( $\sim 5$ drops) was added. The mixture was heated to reflux for $12 \mathrm{~h}$, then concentrated to $\sim 5 \mathrm{~mL}$ by rotary evaporation. The solution was diluted with ethyl acetate $(25 \mathrm{~mL})$ and washed with water several times. The organic layer was dried $\left(\mathrm{MgSO}_{4}\right)$, and concentrated in vacuo. The residue was purified by chromatography $\left(\mathrm{SiO}_{2}\right.$, hexanes-ethyl acetate $\left.=10: 1\right)$ to give $\mathbf{1 1}$ as a colorless crystalline solid (100 mg, 79\%): $\mathrm{mp} 125-127^{\circ} \mathrm{C} ;{ }^{1} \mathrm{H} \mathrm{NMR}\left(\mathrm{CDCl}_{3}\right) \delta 8.04(\mathrm{~m}, 2 \mathrm{H}), 7.87(\mathrm{~m}, 2 \mathrm{H})$, $7.75(\mathrm{~m}, 2 \mathrm{H}), 7.57(\mathrm{~m}, 1 \mathrm{H}), 7.48(\mathrm{~m}, 2 \mathrm{H}), 4.95(\mathrm{~d}, J=9.6 \mathrm{~Hz}, 1 \mathrm{H}), 4.39(\mathrm{dd}, J=5.3,6.5 \mathrm{~Hz}, 1 \mathrm{H}), 3.78(\mathrm{~m}$, $1 \mathrm{H}), 3.62(\mathrm{~s}, 3 \mathrm{H}), 3.44(\mathrm{~s}, 3 \mathrm{H}), 2.91(\mathrm{~m}, 1 \mathrm{H}), 2.01-1.92(\mathrm{~m}, 3 \mathrm{H}), 1.54(\mathrm{~m}, 1 \mathrm{H}) ;{ }^{13} \mathrm{C} \mathrm{NMR}\left(\mathrm{CDCl}_{3}\right) \delta 200.7$, 175.3, 169.2, 167.8, 136.7, 134.5, 133.4, 131.9, 128.9, 128.8, 123.9, 55.0, 52.7, 52.5, 52.4, 49.6, 42.0, 29.9, 29.8. FAB-HRMS $m / z 450.1546$ (calcd for $\mathrm{C}_{25} \mathrm{H}_{24} \mathrm{NO}_{7}\left(\mathrm{M}+\mathrm{H}^{+}\right) \mathrm{m} / \mathrm{z} 450.1553$ ). 